\author{
ONE HUNDRED AND TWELFTH SCIENTIFIC MEETING \\ ROYAL FREE HOSPITAL SCHOOL OF MEDICINE, 8 HUNTER STREET, \\ LONDON, W.C.1
}

I2 OCTOBER I957

\title{
THE NUTRITIVE VALUE OF PROTEINS
}

\author{
Chairman: DR D. P. CUTHBERTSON, C.B.E., M.D., D.Sc., F.R.S.E., \\ Rowett Research Institute, Bucksburn, Aberdeenshire
}

\section{The nutritive value of proteins : general considerations}

\author{
By Kathleen M. Henry and S. K. Kon, National Institute for Research in Dairying, \\ Shinfield, near Reading
}

Earlier concepts of nutrition divided proteins into those of first and those of second class, the former being of animal and the latter of vegetable origin. With increasing knowledge it became evident that the differences between foods as protein sources were reflecting differences in amino-acid composition and also that the superiority of 'first class' protein was often partly due to accompanying vitamins or minerals. We now know that this distinction between animal and vegetable proteins is neither rigid nor always justified.

The value of a food as a source of protein is determined by the concentration of protein in it, the digestibility of the protein, the availability of its amino-acids for the synthesis of tissue protein, and its amino-acid pattern, particularly the content and proportions of the essential amino-acids. Digestibility and amino-acid pattern in turn determine the value of the food protein to the animal. There exist now many biological methods of scoring a protein on this basis, most of which confound these variables into one numerical expression. Bender (1958) deals with these methods in detail. All are designed for and capable of assigning to a protein a relative order of nutritional merit and thus all can be considered as measuring its biological value. Historically the term is associated with the Thomas-Mitchell balance-sheet method (Thomas, I909; Mitchell, I923-4; Mitchell \& Carman, I926) and it is in this sense that we will use it to illustrate some of the more general points with which we are concerned. Mitchell defines the biological value of a protein as the percentage of the absorbed (digestible) nitrogen retained by the body, the endogenous nitrogen losses being allowed for in the calculation.

With young animals such measurement does not distinguish between the needs for growth and maintenance, and the amount of protein in the diet must be low enough (some 8-10\%) to restrict growth, otherwise spuriously low values are obtained.

Another method with which we are concerned is the rat-growth method of Osborne, Mendel \& Ferry (I9I9). In its original form the protein sources were given in the diet at several levels to determine the maximum ratio between gain in 
weight and protein intake (protein efficiency ratio); for all but a very few poor proteins this ratio rises to a maximum and then declines, and less of a good than of a poor protein is needed for maximum response. Nowadays it is customary, but not necessarily justified, to select a single suboptimal protein level, usually $8-10 \%$, for the assessment of proteins by this method.

Normally proteins are considered in relation to their ability to promote growth or to repair body tissues or both. A protein that may be adequate for repair and maintenance in an adult animal may be less satisfactory for the combined functions of growth and repair in the young. For example, wheat flour is, for the rat, relatively deficient in lysine but more so for the young than for the adult; hence the biological value of bread proteins is higher for the adult than for the young rat, 65 as against 55 in a particular instance from our experiments (Henry, Kon \& Rowland, 1946). Further, the value of a protein for certain functions such as replacement and building of specific plasma proteins, haemoglobin and enzymes may be quite different from that for the repair of body tissues as a whole. Thus lactalbumin is superior to casein in promoting the growth of young rats (cf. Henry, I957a,b) but casein has proved better for the regeneration of plasma proteins and the formation of haemoglobin in protein-depleted anaemic dogs (Robscheit-Robbins \& Whipple, r949; Whipple \& Robscheit-Robbins, r95r).

\section{Significance of the amino-acid composition of proteins}

Proteins are composed of some twenty amino-acids. Eight to twelve of them, depending on the species of animal, are termed essential amino-acids, which means that, unlike the other acids, they either cannot be synthesized by the animal or are synthesized too slowly. The following acids are deemed essential for man: valine, leucine, isoleucine, threonine, methionine, lysine, phenylalanine and tryptophan (Rose, 1949). The rat (Rose, I938) and chick (Almquist, 1948) require also histidine and arginine and the chick needs the further addition of glutamic acid and glycine (Almquist, 1948). The rat synthesizes enough arginine for maintenance but not enough for growth (Rose, I938). Certain non-essential acids spare the essential ones; thus cystine can partially replace methionine, and tyrosine and serine respectively spare phenylalanine and glycine.

Naturally any consideration of protein value presupposes that the energy requirements of the animal are fully covered by carbohydrate and fat, otherwise the aminoacids are burnt for fuel.

For the rat the biological value of egg proteins is close on 100 (Mitchell \& Carman, 1926; Hawley, Murlin, Nasset \& Szymanski, I948; Henry \& Kon, 1957) which shows that they are almost completely utilized. Thus the growth rate of rats on a diet containing $9 \%$ of egg proteins could not be improved by the addition of any individual amino-acid, save lysine that had a very slight effect, but increase in the proportion of egg proteins in the diet promoted further growth (Mitchell, 1950).

On account of this near-ideal amino-acid balance, egg proteins are used as a standard of comparison in methods that predict the nutritive value of proteins from 
their amino-acid content and such calculations are in good agreement with results of biological experiments (Block \& Mitchell, I946-7; Oser, I951; Sheffner, Eckfeldt \& Spector, 1956).

\section{Supplementary effects and the time factor in protein utilization}

Maximum utilization of proteins can only take place when the energy needs are satisfied by fat and carbohydrate, and all the essential amino-acids are available simultaneously in the correct proportions, together with adequate quantities of nonessential acids, or of non-protein nitrogen. When one or more of the essential aminoacids are short they are termed limiting acids as they limit the extent to which the particular protein can be used for tissue synthesis.

In a mixed diet with its different proteins supplementary relationships become apparent; whereby amino-acid deficiencies in one food are made good by a relative surplus in another. A protein of highest biological value is not necessarily the most economic in improving less complete proteins. It is the dovetailing of relative aminoacid surpluses and shortages that leads to efficient supplementary relationships between proteins, and with a protein like egg that has nothing to gain on the exchange it may be like robbing Peter to pay Paul. It is possible to predict supplementary effects from amino-acid analyses of individual proteins (Oser, I951; Ramachandran \& Phansalkar, 1956; Edwards, Carter \& Outland, r955) but confirmation by animal experiments is necessary (Ramachandran \& Phansalkar, 1956; Harper, Winje, Benton \& Elvehjem, I955) as some amino-acids may be present in foods in a form that resists enzymic hydrolysis.

High biological values of 80-90 have been reported for the proteins of mixed, non-vegetarian, human diets (Wan \& Lee, 193I; Macrae, Henry \& Kon, I943) and of $73^{-84}$ for cereal and pulse mixtures (Adolph \& Cheng, I935; Lan, r936; Swaminathan, I937, 1938). Few individual proteins have such high biological values so that it is evident that marked supplementary effects must take place.

Table I. Supplementary relationships between protein foods : growth experiments with young rats

\begin{tabular}{|c|c|c|c|c|}
\hline Protein source & $\begin{array}{l}\text { Protein } \\
\text { in diet } \\
(\%)\end{array}$ & $\begin{array}{l}\text { Main amino-acid } \\
\text { deficiency }\end{array}$ & $\begin{array}{l}\text { Gain/week } \\
\text { (g) }\end{array}$ & Reference \\
\hline $\begin{array}{l}\text { Beef-tea } \\
\text { White flour } \\
25 \% \text { beef-tea nitrogen } \\
\quad+75 \% \text { flour nitrogen }\end{array}$ & 12.5 & $\begin{array}{l}\text { All except lysine } \\
\text { Lysine }\end{array}$ & $\begin{array}{r}0 \\
13 \\
19\end{array}$ & Chick \& Slack (r 945) \\
\hline $\begin{array}{l}\text { Wheat gluten } \\
\text { Blood protein } \\
\text { Yeast } \\
50 \% \text { wheat-gluten } \\
\text { nitrogen }+50 \% \text { blood } \\
\text { nitrogen } \\
50 \% \text { yeast nitrogen }+ \\
50 \% \text { blood nitrogen } \\
50 \% \text { wheat-gluten } \\
\text { nitrogen }+50 \% \text { yeast } \\
\text { nitrogen }\end{array}$ & $9 \cdot 0$ & $\begin{array}{l}\text { Lysine } \\
\text { Isoleucine } \\
\text { Methionine }\end{array}$ & $\begin{array}{r}9 \\
8 \\
\text { I I }\end{array}$ & Geiger (I948) \\
\hline
\end{tabular}


Experimental evidence has been obtained in growth and balance experiments with rats. Table I shows that they grew little or not at all when beef-tea and bread (Chick \& Slack, I945) or wheat gluten, blood protein or yeast (Geiger, I948) were the sole source of dietary protein, but that combining these foods in pairs without increasing the total protein caused appreciable growth. Table 2 gives some rather less spectacular examples of supplementary relationships between proteins. Table 3 shows that if equal quantities of protein from bread and from cheese, or from milk and

Table 2. Supplementary relationships between protein foods assessed by measurement of protein efficiency ratios on young rats

\begin{tabular}{lcc}
$\quad$ Protein source & $\begin{array}{c}\text { Protein } \\
\text { efficiency } \\
\text { ratio }\end{array}$ & \multicolumn{1}{c}{$\begin{array}{c}\text { Reference } \\
\text { White flour }\end{array}$} \\
Milk & $1 \cdot 1$ & Quoted by Block \& Mitchell (1946-7) \\
Beef muscle & $3 \cdot 4$ & \\
$50 \%$ flour nitrogen $+50 \%$ milk nitrogen & $3 \cdot 1$ & \\
$50 \%$ flour nitrogen $+50 \%$ beef nitrogen & $3 \cdot 4$ & \\
Parboiled wheat & $3 \cdot 1$ & \\
Chick pea & $1 \cdot 4$ & Adolph, Shammas \& Halaby (1955) \\
$50 \%$ wheat nitrogen $+50 \%$ pea nitrogen & $2 \cdot 1$ & \\
& $2 \cdot 1$ &
\end{tabular}

Table 3. Effect of time interval in consumption on the biological value of proteins of bread and cheese and of potato and milk

\begin{tabular}{|c|c|}
\hline $\begin{array}{r}\text { Biolo } \\
\text { of } \\
f\end{array}$ & $\begin{array}{l}\text { ogical value } \\
\text { f protein } \\
\text { for rats }\end{array}$ \\
\hline $\begin{array}{l}\text { White bread } \\
\text { Cheddar cheese } \\
\text { I part cheese }+3.4 \text { parts bread: given together } \\
\text { given on alternate days }\end{array}$ & $\begin{array}{l}52 \\
76 \\
76 \\
67\end{array}$ \\
\hline Expected value if there were no supplementary relationship & 64 \\
\hline $\begin{array}{l}\text { Potato } \\
\text { Skim milk } \\
\text { I part liquid skim milk }+ \text { I.3 parts potato: given together } \\
\text { given on alternate days }\end{array}$ & $\begin{array}{l}71 \\
89 \\
86 \\
81\end{array}$ \\
\hline Expected value if there were no supplementary relationship & 80 \\
\hline
\end{tabular}

from potato, were given together the biological value of the mixture was the same as that of the animal protein in each pair of foods, but there was no such supplementary effect if the rats received the proteins on alternate days (Henry \& Kon, 1946). Geiger (1948), in growth tests with rats, observed a similar supplementary effect between pairs of proteins when eaten together, but not when one component of the pair was eaten $\mathrm{I} 2 \mathrm{~h}$ before the other (Table 4 ). Young women also retained nitrogen better from a diet supplying $63 \mathrm{~g}$ protein daily when the milk (about $22 \mathrm{~g}$ protein) was distributed equally between three meals than if the breakfast portion was taken with the midday meal (Leverton \& Gram, I949); taking the midday portion 
Table 4. Effect on growth of rats of giving them pairs of proteins together or separated by $a$ I 2 interval

$\begin{array}{lcc}\text { Given together } & \begin{array}{c}\text { Given with } \\ 12 \text { h interval }\end{array} \\ \text { Protein source } & 22 & -0.25 \\ \text { Wheat gluten + blood protein } & 18 & -4 \cdot 0 \\ \text { Yeast + blood protein } & 26 & +2 \cdot 0\end{array}$

in the evening did not affect nitrogen retention (Leverton, Gram \& Chaloupka, I95 I) probably because of the shorter interval between the morning and evening than between the evening and midday meals.

That protein is more efficiently used when eaten with carbohydrate was demonstrated in nitrogen-balance experiments on man (Cuthbertson \& Munro, I939; Elman, 1953) the rat (Cuthbertson, McCutcheon \& Munro, I940; Munro, I949; Geiger, Bancroft \& Hagerty, I950) and the dog (Larson \& Chaikoff, I937). Old customs have, it seems, sound wisdom on their side, and the need to combine milk or other protein concentrates with the staple food they are to supplement might well be kept in mind in the various schemes for the distribution of protein supplements in undernourished countries.

\section{Effect of heat}

Application of heat plays an important part in the preparation of human foods and in the processing of animal feeding-stuffs. Heating causes denaturation of proteins, the extent depending on the severity of the treatment. The full implications of denaturation are not fully understood, but it is broadly considered to be any nonproteolytic modification of the unique structure of a native protein that gives rise to definite changes in its chemical, physical or biological properties.

Many proteins are heated in the cooking or processing of foods, which treatment at times causes losses in nutritive value. Not so, however, with some foods such as egg-white, soya-bean meal and certain legumes which contain a trypsin inhibitor that reduces the rate of enzymic release of one or more of the essential amino-acids. With them mild heat treatment destroys the inhibitor thereby increasing the nutritive value (cf. Griswold, r 951).

Judged by experiments with rats (Table 5), the preparation of meat for the table by roasting, braising or pressure cooking has little effect according to some workers (Clark, Wilmeth, Harrison \& Vail, I955); others found a slight decrease in value after boiling or autoclaving (Morgan \& Kern, r934).

Liquid milk for human consumption is usually pasteurized or sterilized to make it bacteriologically safe. Concentrated forms of milk such as sweetened condensed, evaporated and spray- or roller-dried are also heat-treated at one stage or another of manufacture. Table 6 gives biological values, obtained at Shinfield, for the proteins of such heat-treated milks. Findings in other laboratories are similar. 
Table 5. Effect of cooking on the nutritive value of beef proteins measured on rats

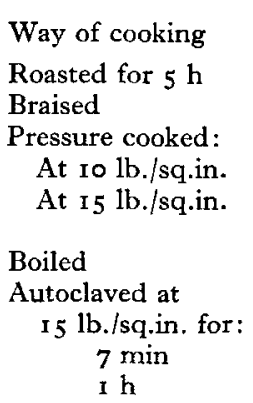

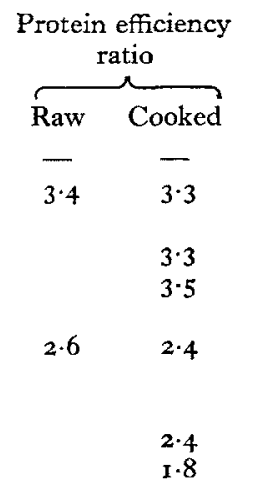

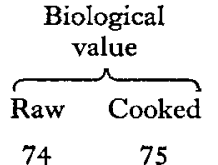

$74 \quad 75$

$-$

$67 \quad 60$
Reference

Mitchell, Hamilton \& Beadles (1949)

Clark et al. (r955)

Morgan \& Kern (1934)

Table 6. Effect of heat on the biological value of milk proteins

Type of milk
Raw
Pasteurized
Condensed (sweetened)
Spray-dried
Roller-dried
Evaporated
Sterilized

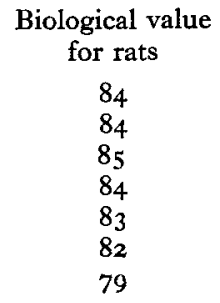

The table shows that the milder heat treatments have little or no deleterious effect on milk proteins. The more drastic ones like sterilization and evaporation may cause some loss in nutritive value. As a general rule prolonged heating at a lower temperature is more injurious than short heating to very high temperatures; for example, some milks exaggeratedly preheated before drying may lose a large proportion of the sulphur amino-acids, cystine and methionine.

Carpenter (1958) and Ellinger (1958) consider in detail the effects of heat treatment in the processing of animal feeding-stuffs.

\section{Effect of storage}

The proteins of dried milk stored under conditions that do not exclude atmospheric moisture deteriorate nutritionally (Henry et al. r946; Hodson \& Krueger, I947; Hodson \& Miller, I957); some loss has also been reported in evaporated milk after storage for 5 years (Hodson, 1952). Results of accelerated storage tests (Henry, Kon, Lea \& White, 1948 ) are shown in Table 7. They demonstrate a rapid fall in the biological value of the proteins of dried skim milk containing $7.3 \%$ moisture but no loss with a moisture content of $4.7 \%$. The loss observed in the highmoisture milk could be rectified by the addition of lysine. The loss is due to inactivation of lysine which, through a Maillard reaction, forms an enzyme-resistant compound with lactose. 
Table 7. Effect of storage on the biological value of milk proteins

\begin{tabular}{|c|c|c|c|}
\hline $\begin{array}{l}\text { Addition to } \\
\text { spray-dried } \\
\text { skim milk }\end{array}$ & $\begin{array}{c}\text { Moisture } \\
\text { content } \\
(\%)\end{array}$ & $\begin{array}{l}\text { Stored } \\
\text { at } 37^{\circ} \\
\text { (days) }\end{array}$ & $\begin{array}{c}\text { Biological } \\
\text { value } \\
\text { for rats }\end{array}$ \\
\hline & $\begin{array}{l}4 \cdot 7 \\
4 \cdot 7\end{array}$ & $\begin{array}{r}0 \\
182\end{array}$ & $\begin{array}{l}86 \\
85\end{array}$ \\
\hline None & & 88 & \\
\hline & $\begin{array}{l}7 \cdot 3 \\
7 \cdot 3\end{array}$ & $\begin{array}{l}20 \\
60\end{array}$ & $\begin{array}{l}03 \\
69\end{array}$ \\
\hline I. $25 \%$ L-lysine & $7 \cdot 3$ & 60 & 87 \\
\hline
\end{tabular}

Similar losses in nutritive value due to storage have been observed with the proteins of maize or wheat (Mitchell \& Beadles, r949; Schulz \& Thomas, I949; Jones, Divine \& Gersdorff, I942), barley (Koch \& Meyer, I957) and soya-bean meal (Mitchell \& Beadles, I949).

\section{Final remarks}

One should not exaggerate the significance of changes due to heating and storage in any one product as they may be of no consequence in a mixed diet, but when the remainder of the diet supplies little good protein they may be serious. Thus in South Africa local dried milk unsatisfactorily stored, and probably unsatisfactorily prepared, was much less efficient in the cure of kwashiorkor than good-quality imported powders (Pretorius, Hansen, Davel \& Brock, I956).

Volumes have been written about the nutritive value and amino-acid composition of isolated proteins or the proteins of separate foods, but for practical purposes much of this work seems to be in a nutritional vacuum. The proof of the pudding is in the eating and what is wanted is reliable assessment of the diets as eaten by animals or man, in health or disease, in plenty or want.

\section{REFERENCES}

Adolph, W. H. \& Cheng, F. W. (1935). Chin. F. Physiol. 9, 245.

Adolph, W. H., Shammas, E. J. \& Halaby, S. H. (1955). Food Res. 20, 31.

Almquist, H. J. (1948). In Proteins and Amino Acids in Nutrition, p. 221 . [M. Sahyun, editor.] New York: Reinhold Publishing Corporation.

Bender, A. E. (1958). Proc. Nutr. Soc. 17, 85 .

Block, R. J. \& Mitchell, H. H. (1946-7). Nutr. Abstr. Rev. 16, 249.

Carpenter, K. J. (1958). Proc. Nutr. Soc. 17, 91.

Clark, H. E., Wilmeth, M. C., Harrison, D. L. \& Vail, G. E. (I955). Food Res. 20, 35.

Chick, H. \& Slack, E. B. (1945). Biochem. F. 39, xxii.

Cuthbertson, D. P., McCutcheon, A. \& Munro, H. N. (I940). Biochem. F. 34, 1002.

Cuthbertson, D. P. \& Munro, H. N. (1939). Biochem. F. 33, 128.

Edwards, C. H., Carter, L. P. \& Outland, C. E. (I955). F. agric. Fd Chem. 3, 952

Ellinger, G. M. (1958). Proc. Nutr. Soc. 17, 100.

Elman, R. (1953). F. clin. Nutr. I, 287.

Geiger, E. (1948). F. Nutr. 36, 813.

Geiger, E., Bancroft, R. W. \& Hagerty, E. B. (1950). F. Nutr. 42, 577.

Griswold, R. M. (195I). F. Amer. diet. Ass. 27, 85.

Harper, A. E., Winje, M. E., Benton, D. A. \& Elvehjem, C. A. (1955). F. Nutr. 56, 187.

Hawley, E. E., Murlin, J. R., Nasset, E. S. \& Szymanski, T. A. (1948). F. Nutr. 36, 153.

Henry, K. M. (1957a). Dairy Sci. Abstr. r9, 603.

Henry, K. M. (1957b). Dairy Sci. Abstr. 19,691.

Henry, K. M. \& Kon, S. K. (1946). F. Dairy Res. 14, $33^{\circ}$. 
Henry, K. M. \& Kon, S. K. (1957). Brit. F. Nutr. 11, 305.

Henry, K. M., Kon, S. K., Lea, C. H. \& White, J. C. D. (I948). F. Dairy Res. 15, 292.

Henry, K. M., Kon, S. K. \& Rowland, S. J. (I946). F. Dairy Res. I4, 403.

Hodson, A. Z. (1952). Food Res. 17, 68.

Hodson, A. Z. \& Krueger, G. M. (I947). Arch. Biochem. 12, 5 I.

Hodson, A. Z. \& Miller, C. B. (r957). Food Tech., Champaign, 1x, 89.

Jones, D. B., Divine, J. P. \& Gersdorff, C. E. F. (I942). Cereal Chem. 19, 819.

Koch, B. A. \& Meyer, J. N. (1957). F. Nutr. 61, 343 .

Lan, T. H. (1936). Chin. F. Physiol. 1o, 637.

Larson, P. S. \& Chaikoff, I. L. (1937). F. Nutr. 13, 287.

Leverton, R. M. \& Gram, M. R. (1949). F. Nutr. 39, 57.

Leverton, R. M., Gram, M. R. \& Chaloupka, M. (195I). 7. Nutr. 44, 537.

Macrae, T. F., Henry, K. M. \& Kon, S. K. (1943). Biochem. F. 37, 225.

Mitchell, H. H. (1923-4). F. biol. Chem. 58, 873 .

Mitchell, H. H. (1950). In Protein and Amino Acid Requirements of Mammals, p. x. [A. A. Albanese, editor.] New York: Academic Press Inc.

Mitchell, H. H. \& Beadles, J. R. (1949). F. Nutr. 39, 463.

Mitchell, H. H. \& Carman, G. G. (1926). F. biol. Chem. 68, 183.

Mitchell, H. H., Hamilton, T. S. \& Beadles, J. R. (1949). F. Nutr. 39, 413.

Morgan, A. F. \& Kern, G. E. (1934). F. Nutr. 7, 367.

Munro, H. N. (1949). F. Nutr. 39, 375.

Osborne, T. B., Mendel, L. B. \& Ferry, E. L. (1919). F. biol. Chem. 37, 223.

Oser, B. L. (195 L). F. Amer. diet. Ass. 27, 396.

Pretorius, P. J., Hansen, J. D. L., Davel, J. G. A. \& Brock, J. F. (I956). S. Afr. med. F. 30, 447.

Ramachandran, M. \& Phansalkar, S. V. (1956). Indian F. med. Res. 44, 501.

Robscheit-Robbins, F. S. \& Whipple, G. H. (1949). F. exp. Med. 89, 359.

Rose, W. C. (1938). Physiol. Rev. 18, I09.

Rose, W. C. (1949). Fed. Proc. 8, 546.

Sheffner, A. L., Eckfeldt, G. A. \& Spector, H. (1956). F. Nutr. 60, 105 .

Schulz, J. A. \& Thomas, B. H. (1949). Cereal Chem. 26, 60.

Swaminathan, M. (I937). Indian F. med. Res. 25, 399.

Swaminathan, M. (1938). Indian $\%$. med. Res. 26, I I 3 .

Thomas, K. (1909). Arch. Anat. Physiol., Lpz., Physiol. Abt. p. 2 19.

Wan, S. \& Lee, W. J. (1931). Chin. F. Physiol. 5, 163.

Whipple, G. H. \& Robscheit-Robbins, F. S. (1951). F. exp. Med. 94, 223.

\section{Biological methods of evaluating protein quality}

By A. E. Bender, Research Department, Bovril Ltd, ${ }_{4} 8$ Old Street, London, E.C.I

Proteins are unique among the foodstuffs in that the same name is given to a large number of heterogeneous substances. It is as if one were considering the nutritional properties of the vitamins as a group, without specifying which vitamin is under consideration. Although the terms fats and carbohydrates each cover a group of substances the properties of all the members of those groups are similar; moreover carbohydrates are subdivided into more specific groupings. With proteins, however, vast numbers of substances of differing composition and differing nutritive value are all covered by the one name.

That the different nutritional values of proteins are not generally taken into account is indicated by the wide acceptance of ' $\mathrm{N} \times 6.25$ ' as an adequate description of protein foods despite the fact that proteins can vary between 0 and $100 \%$ availability for physiological purposes. 